\title{
The role of formal and informal finance in the informal sector in Ghana.
}

\begin{abstract}
Within the developing world, especially Sub-Saharan Africa (SSA), informal small and medium enterprises' (SMEs) access to financing has been extremely limited mainly because of the reluctance of banks and other formal financial institutions to lend to such firms. The impact of this challenge on their growth trajectory has remained relatively indeterminate. This study examines the differential impact of sources of finance on the growth of informal firms in Ghana.
\end{abstract}

We employ the Heckman Selection Technique (HST) to model the selection process of firm financing choices and reverse causality problem. By making use of the World Bank's enterprise survey data on 720 informal firms in Ghana from 2007 - 2010, we find that formal sources of finance, compared to informal sources, are superior in their impact on firms in Ghana. Formal finance institutions, with their ability to provide more than just finance, positively affect firm growth. This result has an important policy implication for the current focus of Government of Ghana in promoting indigenous entrepreneurship through initiatives that will enhance access to financial support of local enterprises in Ghana. In view of this, this study proposes that Government policy towards formal financing institutions and their lending to informal sector need adjustments to provide incentives that will encourage increased lending to informal firms.

JEL Classification: G21, G23, 012, 017

Keywords: Ghana, Firm Growth, Formal Finance, Informal Finance, Informal Firms. 


\section{INTRODUCTION}

Recent studies have highlighted financial constraints as having the most direct and significant impact on firm growth of which firms in Ghana are not an exception (see Beck et al. 2006a; Beck et al. 2014; Ayyagari et al. 2008; Quartey 2002). Despite the underdeveloped nature of the financial system in Africa, studies have revealed how important it is to the economic growth of African countries (Levine 2005; Beck and Cull 2014).

The importance of informal firms cannot be overlooked in the Ghanaian economy. Indeed, studies such as Beck et al. (2006a) and Beck et al. (2011) have established that informal firms can serve as the engine of economic development. In Ghana, about $91 \%$ of small and medium enterprises (SME) are informal firms (Ghana Statistical Service hereafter GSS, 2015), contributing about 70\% of GDP and accounting for 80\% of employment (Abor and Quartey 2010; Homerku 1998). The SME sector in Ghana has provided a source of survival strategy and a source of livelihood to a high percentage of the poor especially after the economic reforms of the early 1980s. Indeed, the informal SME sector started growing fast after the Structural Adjustment Program took place in 1984 and beyond, which led to large-scale retrenchment of labour from the public and more formal sectors of employment. Government's consistent freeze on formal sector employment, the private sector's inability to compete with their foreign counterparts, coupled with the relatively low levels of education ${ }^{1}$ in Ghana, have made it virtually impossible for the formal sector to fully absorb the majority of unemployed persons. Indeed, Nyamekye (2009) provides evidence to show that the size of the informal sector has grown from twice that of the formal sector in the 1980s to five and a half times that of the formal sector in the 1990s. According to GSS (2015), SMEs constitute $98 \%$ of firms within the manufacturing and service sectors, an overwhelming majority of which are in the informal private sector.

\footnotetext{
${ }^{1}$ According to the GSS (2008), 31 percent of Ghanaians who are 15 years and above have never attended school, 55.7 percent have basic education while only 13.6 percent have secondary education or higher.
} 
As noted by Turkson (2010) the growth of the Informal SMEs constitutes the basis for a selfreliant indigenous industrial development and at the same time serves as a place for the development of indigenous entrepreneurship (See also Yankson, 1985). Indeed, if Ghana is to meet its medium-term goals of creating jobs to ensure higher employment, spurring economic growth and facilitating poverty reduction are to be attained, there will be the need to unpack the factors that currently impede the growth of such firms.

The factors that impede SME growth are well documented in the literature. Studies such as Nugent (1996), Fafchamps (1994), Tybout (2000), Sleuwaegen and Goedhuys (2002), Baah-Nuakoh et al. (2002), Turkson (2010), etc. have cited excessive regulation and tax, underdeveloped rural-based production, lack of finance and skilled labor, volatility in business environment, market conditions, infrastructure, technology, transport costs, market size, high information costs, etc. as the main impediments to SME growth in developing countries.

Among these factors, scholars and policy makers have bemoaned the lack of finance as well as the limited access to finance, even if available, as the main SME growth-inhibiting factor. According to Quartey et al. (2017), a brief look at the literature on SME development reveals that inadequacy of funds significantly constrains SME development within SSA (See Aryeetey 1994; World Bank 1994; Arthur 2003; Mensah 2004; Deakins et al. 2008; Okpara 2011). As noted by Quartey et al. (2017) in reference to Collier (2009), the lack of access to finance by SMEs in Africa is unfortunately as a result of two high risk characteristics; namely, generally riskier to provide finance in Africa and riskier to provide finance to small firms globally.

Informal finance emerges as an alternative financing source for firms when bank financing (or formal finance) is difficult to be obtained by firms. A review of the literature indicates that the existence of the financing gap within the SME sector in Africa stems also from the fact that the formal financial sector has over the years been reluctant to give credit to SMEs because of their informality status, lack of collateral and the higher transaction costs of lending to small size firms. 
For instance, Bigsten et al. (2000) observed that about 90\% of small firms are denied credit from the formal financial sector due to their inability to fulfill conditions such as collateral security, leaving them with no alternative than to solely resort to informal finance in the form of personal resources and loans from friends and relatives. As noted by Berg and Fuchs (2013), the share of SME lending in the overall loan portfolios of banks in five Sub-Saharan African countries vary between $5 \%$ and $20 \%$. Indeed, informal financial sources have become the main sources of obtaining the needed financial resource for survival and growth.

Providing anecdotal evidence, Quartey et al. (2017) argue that within the ECOWAS sub-region, there exist two main alternatives to formal SME financing; namely, official schemes (where finance is provided to SMEs by government and/or other international bodies) and informal sources of finance. While the official schemes are often set up with the primary motive of increasing the flow of finance and credit to local SMEs, informal sources of finance for many SMEs in SSA (especially in Nigeria and Ghana) have been in the form of owner's savings, money lenders, friends and relatives, credit and savings associations, very informal "susu" collectors, etc.

The over-reliance on informal sources of finance explains why SMEs in Africa are not growing and transforming to higher size thresholds. Indeed, by its nature informal finance cannot provide adequate resources to support the growth of SMEs in Africa, mainly because of short term repayment and small quantum. Informal finance mainly provides working capital and not funds to expand firms. This explains the emergence of official schemes that seek to increase the flow of finance and credit to SMEs to enable them to expand their operational capacities, increase productivity and improve competitiveness on local and international markets.

Recent debates often revolve around the relative importance of informal versus formal financing (Ayyagari et al. 2010). Ideally, informal finance should be a source for firm growth because informal financiers possess better information and better enforcement tools (through reputation and coercion) than formal financiers and therefore should be more likely to offer credit at a lower 
transaction costs (better screening and monitoring) though of smaller amounts to enhance firm growth.

On the other hand, there are proponents of the growth enhancing impact of formal finance who argue that formal finance is the most important financing source for firm growth because banks are the most efficient financial intermediaries which provide proper screening and monitoring for borrowers while keeping the interest rate at a low level. As a result, it is argued that formal financiers can alleviate the credit constraints of firms better by providing medium to long term resources to help firms grow faster.

This study is motivated to examine the differential impact of the financing options (formal versus informal finance) available to informal SMEs in Ghana and to find out to what extent these financing options propel or impede the growth of such firms. Specifically, this study adds to the recent strand of studies on micro-finance and the development of indigenous entrepreneurship by using firm level data on Ghana to examine financing options and how they can impact firm growth. We extend the literature by looking at only informal firms. This is motivated by the importance of informal firms to the development of developing countries (De soto 1989; Charmes 2000), especially in Ghana where, among other objectives, the current industrial policy seeks to promote indigenous entrepreneurship. Using different techniques, our results show that bank financing promotes firm growth. Our results are robust when we even control for other firm characteristics. We also observe that bank financing has greater impact on large firms, compared to small firms. These large SMEs are more likely to formalize their activities and, hence, contribute significantly to government revenue (De soto 1989).

Our results have several implications. First, they provide a strong basis for policy direction. This outcome provides government and key stakeholders with an understanding and policy direction of how to promote the growth of these informal firms (mainly SMEs) as these firms' growth can be a strong vehicle for economic development of the Ghanaian economy. The right environment 
and the required initiatives can be created for informal firms to access this form of finance. Following these well-directed government initiatives and support, the right platform will be created for informal firms to grow. This study is also in direct response to the current need of the Ghanaian economy, as the national consensus from the recently held national economic reform highlights the strong need for the state to encourage and promote indigenous entrepreneurship as well as provide further steps to support small and medium scale enterprises.

The paper is structured as follows. Section two explores the theoretical background and reviews relevant literature. Section three presents the methodology underpinning the study. In Sections four and five, we present the results and discussion of the results, respectively. Section six presents the conclusion.

\section{THEORETICAL BACKGROUND AND LITERATURE REVIEW}

The increasing demand for finance by SMEs has created the delivery of new forms of financial contracts and encouraged the emergence of studies on how the different forms of finance have influenced firm growth over the years. The inability of SMEs to attain the required growth, despite the increasing use of informal finance, has led firms to seek access to more finance than usual, which may not be available through informal finance. Formal finance would become an obvious option for such firms which are seeking higher levels of growth. However, this comes at a higher cost as the leverage effect of such firms also increases. The leverage effect increases the likely problem of moral hazard. Collateral requirements subsequently become necessary to access formal finance.

Formal finance in this study refers to borrowing from financial institutions such as banks and credit unions and non-bank financial institutions. Informal finance, however, refers to financial resources obtained from Rotating Savings and Credit Associations (ROSCAs), Accumulating 
Savings and Credit Associations (ASCAs), reciprocal/individual finance (e.g. neighbors, friends and family), commercial finance (moneylenders, informal susu operators and cooperatives), etc.

Modigliani and Millers (MM hear after) (1958) explains how capital structural is irrelevant to firm growth and this has stirred up sudden streams of theoretical studies on firm financing. MM's model examined debt and equity financing of a firm in an environment where there was perfect information and hence no transaction cost. In this case, financing structure did not affect the value of the firm but rather the income distributed to the owners of the firm. This model was unrealistic because it assumes no asymmetric information.

Jensen and Meckling (1976) used the agency model to show how imperfect information affected firm growth as well. According to the agency theory, the mismatch of incentives between firm managers and owners can affect the amount of debt or equity holdings of the firm, especially where there is transaction cost involved. This model was more static and did not disaggregate in the form of financing used. Other models such as the pecking order theory and finance growth cycle theory made up for this shortcoming. The pecking order theory, introduced by Myers (1984), showed that firms, especially SMEs, will initially start with internal sources of financing and move to external and formal forms of finance when internal funds become inadequate. This introduced some form of order into the financing options.

Carpenter et al. (2002) showed how choice of financing was dependent on cost of formal and informal financing. They used a financial hierarchy model to show that informal finance is the initial option of choice for small firms as it comes at a lower cost compared to others. Berger and Undell (1998) explored theoretically the view that firms financing can be captured in a continuum. The position of a firm on this continuum was based on firm size, age and information availability. From Figure 1, firms that are small in size and younger have less information to provide to substantiate their credibility in the case of external borrowing and therefore are restricted to internal and informal forms of financing. However, as firms increase in size and grow, they 
accumulate so much information. Where this information is good, it increases the credibility of such firms and how much collateral they can raise or lowers how much collateral will be required. Berger and Undell (1998) extend the financing options to include formal financing in such cases. Most of these models fail to account for the non-financial benefits that firms accrue from formal financial institutions as against informal ones.

Figure 1: Financial cycle theory

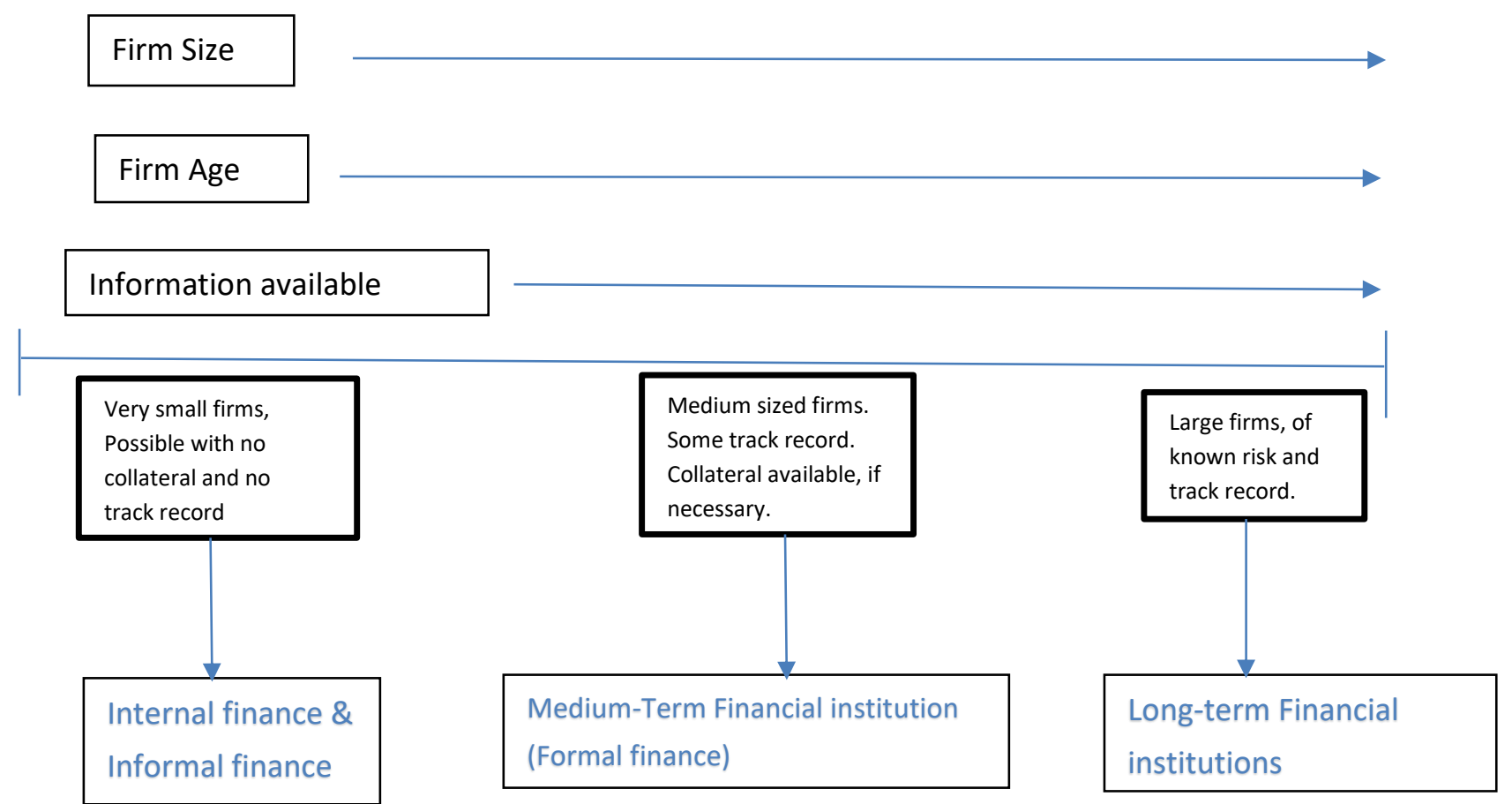

At the macro level, cross-country data has been used to explore the relationship between finance and growth ${ }^{2}$. Most of these studies have used different techniques and different measures of financial development. The results from the majority of these studies have shown that finance indeed promotes growth. However, using cross-country data fails to capture individual country heterogeneity. Some studies have also looked at finance and growth in individual countries. These studies that have looked at individual countries have had the advantage of capturing individual country characteristics. Nevertheless, the difficulty with this approach is that consistent estimates

\footnotetext{
${ }^{2}$ Levine 2005 provides a survey of the different theoretical and empirical evidence provided to examine the relationship between financial development and growth.
} 
from such studies require a long-time span (Christopoulos et al. 2004). Unfortunately, in the case of African countries, such long time series are often not available. In recent times, firm level studies have been favoured as they give greater understanding to the relationship between finance and growth and at the same time account for individual firm and country heterogeneity.

One of the key drivers of sustainable growth in developing countries is firm growth and productivity (Beck et al. 2006b, Beck et al. 2011). Thus, studies have recently resorted to firm level analysis to achieve the objective of higher economic growth. Therefore, understanding firm growth has become a key concern for many researchers and policy makers.

Over the years, studies (such as Turkson 2010; Tybout 2000; Sleuwaegen and Goedhuys 2002 and Baah-Nuakoh et al. 2002) have documented many constraints faced by firms including infrastructure, energy, access to markets, excessive regulation and taxes, volatility in business environment, lack of finance, transport costs, market size, high information costs and macroeconomic instability, especially in developing countries.

However, a fast-growing literature has revealed financial constraints to firms as the most binding of these constraints (Carpenter et al. 2002; Guariglia 2008; Beck et al. 2005; Beck et al. 2006a; Beck et al. 2013, Ayyagari et al. 2008; Quartey 2008). The issue of financial constraints may be especially serious for informal firms ${ }^{3}$ which may not have been in existence for long and may lack collateral. These firms may have two options: formal finance and informal finance. Informal finance may require less information to get funds from lenders due to the less rigorous information requirement though it is normally limited in supply. Hence, informal finance comes at a higher interest rate but low transaction costs. Formal finance on the other hand can help firms overcome financial constraints because of its abundance but may be difficult for informal firms to take advantage of given the collateral requirements. This makes access to finance quite complex for informal firms.

\footnotetext{
${ }^{3}$ Informal firms cover firms that are not legal or partly legal. Such firms have not registered their business or have registration for some parts of the business (Arias et al. 2007)
} 
Khan (2015) examined the impact of different types of funding sources on the growth of small and medium enterprises in Pakistan. Using an Enterprise Survey Data of 78 SMEs in Pakistan over a 3-year period (i.e. 2002, 2007 and 2010), Khan (2015) found the banks playing a positive role toward the growth of SMEs, while in contrast, the informal sources negatively influenced the growth of SMEs between 2002 and 2007. The study therefore recommended, among others, further initiatives to reduce the impediments encountered by SMEs while accessing finance from banks.

Using a survey dataset of Chinese rural households, Beck et al. (2015) found the use of informal finance, especially financing from friends and family, as positively associated with sales growth of microenterprises with employees but not with self-employed enterprises. Beck et al. (2015) do not find any significant relationship between the use of formal finance and firm growth. The findings from the study underline the importance of finance for entrepreneurship and microenterprise growth and the role of informal finance in the absence of efficient formal financial institutions.

According Degryse et al. (2016), different modes of external finance provide heterogeneous benefits for borrowing firms. Using unique survey data from China, they found informal finance to be associated with higher sales growth for small firms but lower sales growth for large firms. Degryse et al. (2016), however, identified a complementary effect between informal and formal finance for the sales growth of small firms, but not for large firms. They concluded that the optimal choice for small firms is to simultaneously make use of the informational advantage of informal finance and the scalability of formal finance to increase their sales.

More recently, Allen et al. (2019) found that constructive informal financing such as trade credits and family borrowing that relies on information advantages or an altruistic relationship is associated with good firm performance, whilst underground financing such as money lenders who make use of violence for enforcement doesn't associate with good firm performance. Allen et al. 
(2019) also found a declining role of constructive informal financing (which was prevalent in regions where access to bank loans was extensive), in supporting firm growth.

\section{Methodology}

a. Data and Summary Statistics

We used the enterprise survey dataset on informal firms in Ghana, conducted in 2013 by the World Bank, to investigate financing patterns and how they impact informal firm growth in Ghana. The survey has information on business activities which cover most SMEs in Ghana. The survey provides information on 729 firms. Industries covered in the survey are manufacturing (365) and services $(364)^{4}$. Firms captured in the survey are a fair representation across the major urban areas in Ghana. Out of the 729 firms, 176 (24\%) firms were based in Accra, 189 (26\%) were based in the North (Kumasi and Tamale), 184 (25\%) firms were based in Tema and 180 (25\%) firms were based in Takoradi.

The survey questionnaires provide a wider range of information about the firms captured. They cover 10 sections including sales and supply, finance, business productivity, labour, crime, registration and business environment, business general information and ownership and business activity and location. These details allowed us to also make use of firm size, ownership structure and financing types to investigate our main objective. To examine the best form of financing that produces higher firm growth, we looked at the overall relevance of finance as a constraint for these firms.

Using information on the constraints faced by firms, we explored overall finance as a binding constraint to firm growth in comparison to the other constraints. We identified that finance is the

\footnotetext{
${ }^{4}$ The manufacturing sector includes food products, beverage, wearing apparel, leather products, furniture and metal products, household (consumer) products, and other manufacturing. The service sector includes communication services, professional services, household services and food and beverage services, selling of wearing apparel services, selling of other goods.
} 
biggest obstacle faced by informal firms in Ghana. Out of the eight factors ${ }^{5}$ highlighted as constraints to firm growth, 264 firms (representing 38\%) considered finance as their major constraint to the growth of business. This was the highest amongst the eight factors. In addition to this, more than half of all the firms in the data identified finance as constraint when managers of these firms were asked if finance was a constraint. ${ }^{6}$ This confirms that indeed finance plays an important role in the smooth running of these firms.

Table 1: regional, sectoral and financing options

\begin{tabular}{|l|c|c|}
\hline Regions & Frequency & Percent \\
\hline Accra & 176 & 24.14 \\
\hline North & 189 & 25.93 \\
\hline Takoradi & 180 & 24.69 \\
\hline Tema & 184 & 25.24 \\
\hline Sector & Frequency & Percent \\
\hline Manufacturing & 365 & 50.07 \\
\hline Services & 364 & 49.93 \\
\hline Financing options & Frequency & Percent \\
\hline Internal Finance & 618 & 86.19 \\
\hline Operational finance & 40 & 5.58 \\
\hline Money lenders finance & 4 & 0.56 \\
\hline Microfinance & 24 & 3.35 \\
\hline Bank finance & 12 & 1.67 \\
\hline Informal finance & 19 & 2.65 \\
\hline
\end{tabular}

To examine the relationship between firm financing patterns and firm growth, we explored the rich data for the complete view of the financing options available to the firms. There are six different forms of financing used by informal firms in Ghana. Firms make use of internal finance, operational finance, money lenders, microfinance institutions, bank finance, and informal finance?

\footnotetext{
5 The 8 factors identified by the firms were limited access to finance, limited access to land, corruption, crime, problems with electricity supply, problems with water supply, limited access to technology, inadequately educated workforce. Out these 8 , limited access to finance, problems with electricity supply and limited access to land were the 3 highest factors indicated by the firms.

${ }^{6}$ Out of 729 firms, 314 firms (53\%) indicated finance as a constraint and $278(49 \%)$ indicated finance was not a constraint. The other 137 firms had no response for these questions.

${ }^{7}$ Informal finance captures financing from family and friends. Bank finance covers financing from commercial banks. Internal finance is finance through retained earnings from the business; operational finance is finance from suppliers and customer trade credit, money lenders is finance from business and individuals predominantly of the Money Lenders Association, Ghana, micro financing is finance from small size institutions.
} 
Of these, internal finance is the most commonly used form of financing. $85 \%$ of the firms in the survey use internal finance. This is acceptable given that firms in the survey are all informal firms which may not have the right provision to borrow from formal sources. This is a similar phenomenon in other developing countries where most firms make use of internal financing compared to alternative options (See Allen et al. 2005; Ayyagari et al. 2010; Girma et al. 2012; Guariglia et al. 2013). Even with regional analysis, this pattern is consistent across all the regions. For Operational Financing, the north has the highest percentage of firms which use this kind of finance.

Table 2: Distribution of financing option across regions

\begin{tabular}{|l|r|r|r|r|r|r|r|}
\hline Region & $\begin{array}{l}\text { Internal } \\
\text { Finance }\end{array}$ & $\begin{array}{l}\text { Operational } \\
\text { finance }\end{array}$ & $\begin{array}{l}\text { Money } \\
\text { lenders } \\
\text { finance }\end{array}$ & Microfinance & $\begin{array}{l}\text { lank } \\
\text { finance }\end{array}$ & $\begin{array}{l}\text { Informal } \\
\text { finance }\end{array}$ & \multicolumn{1}{l|}{ Total } \\
\hline Accra & 156 & 10 & 1 & 3 & 2 & 4 & 176 \\
\hline North & 150 & 14 & 0 & 8 & 3 & 4 & 189 \\
\hline Takoradi & 149 & 8 & 0 & 8 & 5 & 8 & 180 \\
\hline Tema & 163 & 8 & 3 & 5 & 2 & 3 & 184 \\
\hline Total & 618 & 40 & 4 & 24 & 12 & 19 & 729 \\
\hline
\end{tabular}

We also observed that for finance from money lenders, the majority of firms in Tema make use of this form of finance, while Takoradi has the highest percentage of firms which use bank financing and informal financing options. For internal finance we observed a very slight difference across the region. Tema firms had a slight majority of less than 2 per cent compared to the other regions. For firm size ${ }^{8}, 75 \%$ of the large firms use more of bank financing compared to small firms but $66 \%$ of small firms use finance from microfinance institutions. With reference to internal financing and operational financing, 51\% of large firms use internal financing and $70 \%$ of operational financing. For informal financing, 53\% of small firms make use of operational finance.

\footnotetext{
${ }^{8}$ Following Zingales et al. (2000) Firm size is determined by using the average cost of labour.
} 
There is an equal percentage of usage when we looked at money lenders as a source of financing across firm size. ${ }^{9}$

Table 3: Distribution of financing option across firm characteristics

\begin{tabular}{|c|c|c|c|c|c|c|c|}
\hline & $\begin{array}{l}\text { Internal } \\
\text { Finance }\end{array}$ & $\begin{array}{l}\text { Operational } \\
\text { finance }\end{array}$ & $\begin{array}{l}\text { Money } \\
\text { lenders } \\
\text { finance }\end{array}$ & Microfinance & $\begin{array}{l}\text { Bank } \\
\text { finance }\end{array}$ & $\begin{array}{l}\text { Informal } \\
\text { finance }\end{array}$ & Total \\
\hline \multicolumn{8}{|l|}{ Firm size } \\
\hline small firm & 48.38 & 30 & 50 & 66.67 & 25 & 52.63 & 47.7 \\
\hline large firm & 51.62 & 70 & 50 & 33.33 & 75 & 47.37 & 52.3 \\
\hline \multicolumn{8}{|l|}{ AGE } \\
\hline less than 5 years & 31.67 & 17.5 & 0 & 37.5 & 8.33 & 52.63 & 31.04 \\
\hline $\mathrm{b} / \mathrm{n} 5$ and 20 years & 61.83 & 65 & 75 & 54.17 & 66.67 & 47.37 & 61.52 \\
\hline greater than 20 years & 6.5 & 17.5 & 25 & 8.33 & 25 & 0 & 7.44 \\
\hline \multicolumn{8}{|l|}{ OWNERSHIP } \\
\hline Joint partnership & 10.05 & 7.5 & 0 & 4.17 & 0 & 26.32 & 9.92 \\
\hline Sole proprietor & 89.95 & 92.5 & 100 & 95.83 & 100 & 73.68 & 90.08 \\
\hline \multicolumn{8}{|l|}{ LEGAL STATUS } \\
\hline Non registered firms & 97.52 & 100 & 100 & 100 & 91.67 & 100 & 97.72 \\
\hline registered & 2.48 & 0 & 0 & 0 & 8.33 & 0 & 2.28 \\
\hline \multicolumn{8}{|l|}{ EDUCATION } \\
\hline No Education & 11.09 & 28.21 & 0 & 8.7 & 16.67 & 5.26 & 11.83 \\
\hline Primary Education & 45.02 & 38.46 & 75 & 52.17 & 50 & 42.11 & 45.07 \\
\hline Secondary Education & 31.32 & 23.08 & 25 & 30.43 & 16.67 & 36.84 & 30.7 \\
\hline Vocational Training & 8.81 & 0 & 0 & 8.7 & 0 & 5.26 & 8.03 \\
\hline Tertiary Education & 3.75 & 10.26 & 0 & 0 & 16.67 & 10.53 & 4.37 \\
\hline
\end{tabular}

\section{b. The empirical model}

We examined the relationship between financing type and firm growth by estimating the following model:

$$
\begin{gathered}
S_{i}=\alpha_{0}+\beta_{1} B F_{i}+\beta_{2} A_{i}+\beta_{3} L S_{i}+\beta_{4} F S_{i}+\beta_{5} O W N_{i}+\beta_{6} C O M_{i}+\beta_{7} E D U_{i}+\beta_{8} P O W_{i} \\
+\gamma_{R}+\gamma_{I}+\varepsilon
\end{gathered}
$$

\footnotetext{
${ }^{9}$ We did similar analysis of firm financing across Ownership, firm age and educational level of the largest owner.
} 
We used log of sales as the main dependent variable (S). More productive firms generally have higher sales and higher sales promote firm growth. Therefore, sales of firms are commonly used in the finance literature as a measure of firm productivity (e.g. Helpman et al. 2004; Helpman et al. 2008; Yeaple 2005). We used different measures, including average total sales, highest total sales, lowest sales, busiest month total sales. We also employed labour productivity as an alternative measure. Subscript i represents each firm. Our main independent variable is defined on the basis of past financing sources, current financing sources, and financing sources of new investment ${ }^{10}$. First, to capture past financing pattern, we constructed a Past Finance Dummy. It takes the value of 1 if firm financed day-to-day operation of the business in the previous years with bank loan. This represents a formal form of financing. It takes the value of 0 if financing came from an informal source. Bank loans include financing from banks and microfinance institutions. This captures formal financing pattern versus informal financing. This is represented by BF in the baseline regression. For robustness, we used different variables to measure our main independent variable. We used Bank Dummy as an alternative independent variable which takes the value of 1 if firm currently has a bank loan. We also constructed another measure which captures how firms finance new investment. This variable - Investment Financing Dummy - takes on a value of one if new investment is financed with bank loan and zero otherwise.

All estimations are done in the presence of other control variables (age, firm size, ownership, legal status, level of competition, regional dummy) that impact firm growth and productivity. For the dependent variable, we used different measures of sales growth. $A$ represents the age of the firm. The age variable is a categorical variable captured in the following order: 1 for firms that are less than five years old, two for firms that are between five and twenty years old and three for firms that are more than twenty years old (See Girma et al. 2012; Ayyagari et al. 2011; Guariglia et al. 2011 for similar classification). $L S$ represents the legal status of the firm. It is a dummy variable

${ }^{10}$ We follow a similar approach by Allen et al., 2005, Ayyagari et al., 2010. 
that identifies firms that are legally registered with the state and those that are not. Registered firms are better recognised in the goods and labour market compared to non-registered ones (Christensen et al., 2004). OWN captures the ownership structure of the firm. It is a dummy variable that takes the value of 1 if the firm is a sole proprietor and 0 if otherwise ${ }^{11}$ (For similar examples, see Xu et al., 2009; Shliefer, 1998; Megissons et al., 2001). Firm size is represented by FS. For most constraints that affect a firm's growth negatively, small-sized firms tend to have the greatest slump in their growth (Beck et al., 2005). Small-sized firms are likely to be more constrained financially than large ones. Following Zingales et al. (2000), we computed the FS variable using labour cost. It is represented by a dummy variable that takes on 1 if the firm's cost is greater than the average labour cost and 0 if the firm's labour cost is less than the average labour cost. EDU captures the level of education of the owner with the biggest share of the firm ${ }^{12}$. For firms with highly educated managers, it is expected that on average such firms will be bettermanaged (Magoutas et al., 2012). In this study, we used a categorical variable to represent the EDU variable, which takes on the value of 1 if the owner with the biggest share has no education to 5 where the largest owner has a tertiary level of education. Given the current high power outages in Ghana $^{13}$, we controlled for it by including a dummy variable to capture it. It takes on the value of 1 if firms identified electricity outages as a constraint to their business and 0 for otherwise. It is represented by POW in the baseline regression. Also, the more competitive the industrial environment is, the more difficult it is for informal firms to survive especially if they are small and young. Thus, we also controlled for this by using a dummy variable which takes the value of 1 if the firm is located in a city centre and 0 for otherwise. $\gamma_{R}$ and $\gamma_{I}$ represent regional and industry specific characteristics that may have been omitted.

\footnotetext{
${ }^{11}$ Because the survey covers only informal firms, the data are dominated by sole proprietor and partnerships.

12 Primarily, the largest owner has the greatest influence on decision making in the business.

${ }^{13}$ See Asamoah et al., (2014) for a study on power fluctuations on SME's profitability.
} 
We first used Ordinary Least Square (OLS) as a first step to examine equation one. Reverse causality should not be a major issue in this study given that our aim was to examine which financing pattern is associated with high firm growth. However, if a firm's ability to obtain finance is influenced by certain firm characteristics such as ownership personality (for example education qualification) and these firm characteristics also influence firm growth, then there may be issues with endogeneity. We therefore explored other two estimation techniques to deal with this. First, we used the instrumental variable technique by instrumenting for the Bank financing dummy variable with collateral, through Two Stage Least Squares (2SLS) estimation. A firm's ability to present collateral influences its ability to receive financing. However, collateral is not directly related to a firm's growth, making it a good instrument (Boot et al. 1994; Ayyagari et al. 2008). Secondly, we used the Heckman selection model as an additional robustness test. The model is relevant given that bank financing decision by firms may not be random. Sometimes, based on preferences, they make the decision to choose a particular form of financing. They self-select and hence draws are not random from the population but from a specific sample. If this is the case, then the OLS estimates will be biased (Li et al. 2009). The error term will no longer be white noise.

The Heckman Selection technique involves a two-step approach. In step 1, we estimated a selfselection equation to draw justification for self- selection. In step two, we estimated the variable drawn from the selection on our dependent variable. Following Ayyagari et al. 2010, we estimated the selection equation below using collateral as our instrument:

$$
\begin{aligned}
& B F=1 \text { if } \\
& =\alpha_{0}+\beta_{1} \text { Collateral }+\beta_{2} A+\beta_{3} L S+\beta_{4} F S+\beta_{5} O W N+\beta_{6} C O M+\beta_{7} E D U+\beta_{8} P O W+ \\
& \gamma_{R}+\gamma_{I}+\epsilon>0
\end{aligned}
$$

Equation 2 is our selection model and out of it we obtained the inverse Mills ratio to adjust second step of the Heckman model: 
$S=\alpha_{1}+\delta_{1} B F+\delta_{2} A+\delta_{3} L S+\delta_{4} F S+\delta_{5} O W N+\delta_{6} C O M+\delta_{7} E D U+\delta_{8} P O W+\sigma_{R}+$

$\sigma_{I}+\theta+\varepsilon$

where $\theta$ is the inverse Mills ratio accounting for omitted variable bias.

\section{RESULTS}

Table 4 below presents results from equation 1. We find a positive association between formal financing and firm performance. Across all columns, the bank financing variable (Past finance dummy) is positive and strongly significant for different indicators of the dependent variable ${ }^{14}$. This indicates the relevance of bank financing to informal firms in Ghana. Control variables also mostly had the right signs and were significant. Firm size was positive for all and significant in columns 2 to 5 . This indicates a positive association between firm size and firm performance; bigger firms have higher growth. We also obtained a stronger relationship for education level of the largest owner. This supports the literature on the impact of education in the workplace.

Table 4: Firm growth and financing-baseline regression-Past Finance Dummy

\begin{tabular}{|c|c|c|c|c|c|}
\hline VARIABLES & $\begin{array}{c}\text { TSMP } \\
(1)\end{array}$ & $\begin{array}{l}\text { TS } \\
\text { (2) }\end{array}$ & $\begin{array}{c}\text { ATS } \\
(3)\end{array}$ & $\begin{array}{c}\text { TSSM } \\
(4)\end{array}$ & $\begin{array}{c}\text { TSBM } \\
\text { (5) }\end{array}$ \\
\hline Past Finance Dummy & $\begin{array}{c}0.379 * * * \\
(0.114)\end{array}$ & $\begin{array}{c}0.400 * * * \\
(0.107)\end{array}$ & $\begin{array}{c}0.277^{*} \\
(0.162)\end{array}$ & $\begin{array}{c}0.512 * * * \\
(0.117)\end{array}$ & $\begin{array}{c}0.380 * * * \\
(0.105)\end{array}$ \\
\hline Age & $\begin{array}{c}0.131 \\
(0.087)\end{array}$ & $\begin{array}{c}0.176 * * \\
(0.078)\end{array}$ & $\begin{array}{l}0.226^{*} \\
(0.129)\end{array}$ & $\begin{array}{c}0.130 \\
(0.090)\end{array}$ & $\begin{array}{l}0.147^{*} \\
(0.086)\end{array}$ \\
\hline legal status & $\begin{array}{c}0.649 \\
(0.536)\end{array}$ & $\begin{array}{l}0.659 * \\
(0.365)\end{array}$ & $\begin{array}{c}0.137 \\
(0.393)\end{array}$ & $\begin{array}{l}0.708^{*} \\
(0.397)\end{array}$ & $\begin{array}{c}0.567 \\
(0.365)\end{array}$ \\
\hline firm size & $\begin{array}{c}0.126 \\
(0.116)\end{array}$ & $\begin{array}{c}0.210^{* *} \\
(0.103)\end{array}$ & $\begin{array}{c}0.340^{* *} \\
(0.158)\end{array}$ & $\begin{array}{l}0.215^{*} \\
(0.113)\end{array}$ & $\begin{array}{c}0.319 * * * \\
(0.111)\end{array}$ \\
\hline Ownership & $\begin{array}{l}-0.031 \\
(0.155)\end{array}$ & $\begin{array}{c}0.087 \\
(0.154)\end{array}$ & $\begin{array}{c}0.083 \\
(0.187)\end{array}$ & $\begin{array}{c}0.179 \\
(0.166)\end{array}$ & $\begin{array}{c}0.212 \\
(0.158)\end{array}$ \\
\hline Competition & $\begin{array}{c}0.031 \\
(0.100)\end{array}$ & $\begin{array}{l}-0.002 \\
(0.094)\end{array}$ & $\begin{array}{l}-0.214 \\
(0.154)\end{array}$ & $\begin{array}{l}-0.115 \\
(0.103)\end{array}$ & $\begin{array}{l}-0.092 \\
(0.101)\end{array}$ \\
\hline education level & $\begin{array}{c}0.144 * * \\
(0.058)\end{array}$ & $\begin{array}{c}0.167 * * * \\
(0.055)\end{array}$ & $\begin{array}{c}0.247^{* * *} \\
(0.083)\end{array}$ & $\begin{array}{l}0.107 * \\
(0.058)\end{array}$ & $\begin{array}{c}0.180 * * * \\
(0.058)\end{array}$ \\
\hline electricity outage & $\begin{array}{l}-0.022 \\
(0.109)\end{array}$ & $\begin{array}{l}-0.072 \\
(0.101)\end{array}$ & $\begin{array}{c}0.074 \\
(0.163)\end{array}$ & $\begin{array}{c}0.046 \\
(0.111)\end{array}$ & $\begin{array}{l}-0.058 \\
(0.108)\end{array}$ \\
\hline
\end{tabular}

${ }^{14}$ All columns of the results table were significant at $1 \%$ except column 3 which was significant at $10 \%$. We attribute this to the loss of sample due to missing data for the average sales variable. 


\begin{tabular}{lccccc}
\hline Constant & $5.043^{* * *}$ & $5.669^{* * *}$ & $5.087^{* * *}$ & $5.138^{* * *}$ & $5.438^{* * *}$ \\
& $(0.303)$ & $(0.293)$ & $(0.423)$ & $(0.308)$ & $(0.309)$ \\
& & & & & \\
Observations & 563 & 573 & 256 & 567 & 564 \\
R-squared & 0.063 & 0.095 & 0.110 & 0.086 & 0.088 \\
\hline
\end{tabular}

Robust standard errors in parentheses: ${ }^{* * *} \mathrm{p}<0.01,{ }^{* *} \mathrm{p}<0.05,{ }^{*} \mathrm{p}<0.1$. All regressions include regional and industry dummies. TSMP is Total Sales of the Main Product, TS-Total sales, ATS-Average Total Sales, TSSM-Total Sales of the Slowest Month, TSBM-Total Sales of the Busiest Month.

The Age variable was positive and mostly significant, indicating that there is a positive impact on those firms that manage to survive and remain in the industry. Formal registration of a business (represented by legal) seems to be beneficial to those firms which had done so. However, the impact of competition, ownership and electricity outages were not significant even though they had the right signs in some cases.

For robustness, we investigated whether our financing variable is not driving the results. In addition, given that the past finance dummy variable was capturing firms and their financing behaviour in the past, we introduced two new alternative measures to capture current and future financing behaviour.

In Table 5, we present similar results of equation 1 but with bank finance dummy as the financing variable. This captures the current financing behaviour of firms and establishes that our previous results are still robust. As we can see, we obtained similar results. We found a positive relationship between bank financing and firm growth. In Columns 2, 4 and 5 our results for bank financing are also statistically significant. Once again, the results confirm that formal forms of finance were associated with higher firm performance. We also used the investment finance dummy, which captures how a new investment was financed. Results of this estimation can be found in the second column of Table 5. Our bank financing variable is positive in all cases except for column 3. This is also statistically significant in columns 1 and 2 confirming our results that formal financing options are more relevant than informal options to firms in financing their growth. 
Table 5: Firm growth and financing-baseline regression-Bank Dummy \& Investment Finance Dummy

\begin{tabular}{lccccc}
\hline VARIABLES & TSMP & TS & ATS & TSSM & TSBM \\
& $(1)$ & $(2)$ & $(3)$ & $(4)$ & $(5)$ \\
\hline \multirow{3}{*}{ Bank Dummy } & & & & & \\
& 0.150 & $0.328^{* *}$ & 0.226 & $0.383^{* *}$ & $0.310^{* *}$ \\
Investment Finance Dummy & $(0.153)$ & $(0.147)$ & $(0.206)$ & $(0.154)$ & $(0.143)$ \\
& $0.077^{* *}$ & $0.072^{* *}$ & -0.055 & 0.044 & 0.040 \\
& $(0.035)$ & $(0.029)$ & $(0.037)$ & $(0.044)$ & $(0.032)$
\end{tabular}

\section{Controls}

Age, legal status, firm size, Ownership, Competition, education, electricity outages

Robust standard errors in parentheses: ${ }^{* * *} \mathrm{p}<0.01,{ }^{* *} \mathrm{p}<0.05,{ }^{*} \mathrm{p}<0.1$. All regressions include regional and industry dummies. TSMP is Total Sales of the Main Product, TS-Total sales, ATS-Average Total Sales, TSSM-Total Sales of the Slowest Month, TSBM-Total Sales of the Busiest Month.

We also examined the robustness of our results with a change to the dependent variable. We used a more direct measure of firm efficiency. Labour productivity growth is used in place of our sales variable as dependent variable. We estimated equation one using all three indicators of formal financing, respectively, with labour productivity as the dependent variable in each case. From the results in Table 6, bank financing is positively associated with higher firm performance. For each of the bank financing variables, we obtained a positive relationship.

Table 6: Firm growth and financing-baseline regression-Labour Productivity Growth (LPG)

\begin{tabular}{lcccc}
\hline VARIABLES & $\begin{array}{c}\text { LPG } \\
(\mathbf{1})\end{array}$ & $\begin{array}{c}\text { LPG } \\
\mathbf{( 2 )}\end{array}$ & $\begin{array}{c}\text { LPG } \\
\mathbf{( 3 )}\end{array}$ & $\begin{array}{c}\text { LPG } \\
\mathbf{( 4 )}\end{array}$ \\
\hline \multirow{2}{*}{ Investment Finance Dummy } & & & & \\
& $\mathbf{0 . 0 7 9 *}$ & & & \\
Bank Dummy & $\mathbf{( 0 . 0 4 2 )}$ & & & \\
& & $\mathbf{0 . 0 2 8}$ & & \\
Past Finance Dummy & & $\mathbf{( 0 . 1 7 8 )}$ & & $\mathbf{0 . 2 8 1 * *}$ \\
& & & & $\mathbf{( 0 . 1 3 5 )}$ \\
Constant & & & & \\
& $6.372^{* * *}$ & $4.361^{* * *}$ & $6.372^{* * *}$ & $5.501^{* * *}$ \\
& $(0.462)$ & $(0.322)$ & $(0.462)$ & $(0.342)$
\end{tabular}

\section{Controls}

Observations

R-squared
Age, legal status, firm size, Ownership, Competition, education, electricity outages

$\begin{array}{cccc}237 & 497 & 237 & 498 \\ 0.185 & 0.110 & 0.185 & 0.117\end{array}$

Robust standard errors in parentheses: $* * * p<0.01, * * p<0.05, * p<0.1$. All regressions include regional and industry dummies. LPG- Labour Productivity Growth 
Our results so far have shown that bank financing is positively associated with firm performance.

However, we need to ensure that this is not influenced by the large firms in the sample (Beck et al., 2006) ${ }^{15}$. Like the outliers in the sample of many large informal firms, they could drive the results. Therefore, we explored the relationship between financing and firm growth for the respective firm sizes. We estimated equation 1 for large firms and small firms, respectively. Interestingly, the results from Table 7 shows that our earlier result is robust against any possible size effect. We obtained a positive coefficient for all estimations, indicating a positive relationship between bank financing and firm performance. A closer look at the coefficient estimate reveals a bigger estimate for large firms. For example, in Column 1, a unit change in our bank finance (Past Finance Dummy) will lead to a 45\% change in a firm's performance, all other things being equal, for larger firms, compared to $27 \%$ change in a firm's performance. A similar pattern is observed in the other columns.

Table 7: Firm growth and financing-The Size effect

\begin{tabular}{lccccc}
\hline \multicolumn{7}{c}{ Large firms } & & & \\
\hline VARIABLES & TSMP & TS & ATS & TSSM & TSBM \\
& $(1)$ & $(2)$ & $(3)$ & $(4)$ & $(5)$ \\
Past Finance & $0.446^{* *}$ & $0.463 * * *$ & 0.377 & $0.646^{* * *}$ & $0.427^{* *}$ \\
Dummy & \multicolumn{7}{c}{ Small firms } & & & \\
& $(0.190)$ & $(0.175)$ & $(0.245)$ & $(0.178)$ & $(0.171)$ \\
\hline \multicolumn{7}{c}{ VARIABLES } & TSMP & TS & ATS & TSSM & TSBM \\
& $(1)$ & $(2)$ & $(3)$ & $(4)$ & $(5)$ \\
Past Finance & $0.269 * *$ & $0.296^{* *}$ & 0.027 & $0.340 * *$ & $0.305^{* *}$ \\
Dummy & & & & & \\
& $(0.134)$ & $(0.132)$ & $(0.209)$ & $(0.156)$ & $(0.129)$
\end{tabular}

Controls Age, legal status, firm size, Ownership, Competition, education, electricity outages

Robust standard errors in parentheses: ${ }^{* * *} \mathrm{p}<0.01,{ }^{*} \mathrm{p}<0.05,{ }^{*} \mathrm{p}<0.1$. All regressions include regional and industry dummies. TSMP is Total Sales of the Main Product, TS-Total sales, ATS-Average Total Sales, TSSMTotal Sales of the Slowest Month, TSBM-Total Sales of the Busiest Month.

\footnotetext{
${ }^{15}$ In a paper by Beck et al., (2006), they showed how the impact of legal and financial constraints on firm growth depended heavily on firm size. Small firms were greatly constrained by such problems.
} 


\subsection{Robustness tests}

\subsubsection{Firm performance and financing options-Instrumental Variable regression}

Despite the robust results evidenced above, there is also a plausible case of endogeneity in the relationship examined above. A firm with a good firm performance is more likely to obtain bank finance and other forms of finance. If we wish to determine a causal relationship, then we need to address the possible bi-causal nature of the relationship between financing options and firm performance. Furthermore, the presence of other characteristics that can influence a firm's ability to obtain finance and their growth contribute to possible endogeneity.

Table 8: Firm growth and financing-Instrumental Variable regression ${ }^{16}$

\begin{tabular}{lccccc}
\hline VARIABLES & $\begin{array}{c}\text { TSMP } \\
(\mathbf{1})\end{array}$ & $\begin{array}{c}\text { TS } \\
\mathbf{( 2 )}\end{array}$ & $\begin{array}{c}\text { ATS } \\
\mathbf{( 3 )}\end{array}$ & $\begin{array}{c}\text { TSSM } \\
\mathbf{( 4 )}\end{array}$ & $\begin{array}{c}\text { TSBM } \\
\mathbf{( 5 )}\end{array}$ \\
\hline Past Finance & $\mathbf{0 . 2 1 5}$ & $\mathbf{0 . 4 1 9 * *}$ & $\mathbf{0 . 3 7 5}$ & $\mathbf{0 . 5 9 2 * * *}$ & $\mathbf{0 . 4 3 6 * *}$ \\
Dummy & & & & & \\
& $\mathbf{0 . 1 8 4 )}$ & $\mathbf{( 0 . 1 8 3 )}$ & $\mathbf{( 0 . 2 4 9 )}$ & $\mathbf{( 0 . 1 8 2 )}$ & $\mathbf{( 0 . 1 7 2 )}$ \\
Age & 0.134 & $0.176^{* *}$ & $0.228^{*}$ & 0.129 & $0.146^{*}$ \\
& $(0.087)$ & $(0.077)$ & $(0.126)$ & $(0.089)$ & $(0.084)$ \\
legal status & 0.634 & $0.661^{*}$ & 0.146 & $0.717^{*}$ & 0.573 \\
& $(0.530)$ & $(0.362)$ & $(0.386)$ & $(0.394)$ & $(0.362)$ \\
firm size & 0.134 & $0.209^{* *}$ & $0.336^{* *}$ & $0.211^{*}$ & $0.317^{* * *}$ \\
& $(0.115)$ & $(0.101)$ & $(0.153)$ & $(0.111)$ & $(0.110)$ \\
Ownership & -0.022 & 0.086 & 0.076 & 0.173 & 0.208 \\
& $(0.155)$ & $(0.152)$ & $(0.182)$ & $(0.165)$ & $(0.157)$ \\
Competition & 0.019 & -0.000 & -0.208 & -0.108 & -0.087 \\
& $(0.099)$ & $(0.094)$ & $(0.149)$ & $(0.102)$ & $(0.101)$ \\
education level & $0.140^{* *}$ & $0.167 * *$ & $0.247 * * *$ & $0.110^{*}$ & $0.182^{* * *}$ \\
& $(0.058)$ & $(0.055)$ & $(0.081)$ & $(0.057)$ & $(0.057)$ \\
electricity outage & -0.018 & -0.073 & 0.070 & 0.042 & -0.061 \\
& $(0.108)$ & $(0.100)$ & $(0.159)$ & $(0.111)$ & $(0.108)$ \\
Constant & $5.507 * * *$ & $5.664^{* * *}$ & $5.069^{* * *}$ & $5.121^{* * *}$ & $5.967 * * *$ \\
& $(0.315)$ & $(0.290)$ & $(0.411)$ & $(0.303)$ & $(0.308)$ \\
& & & & & \\
First stage F-stat & 389.734 & 443.447 & 454.341 & 434.584 & 389.734 \\
& $(0.000)$ & $(0.000)$ & $(0.000)$ & $(0.000)$ & $(0.000)$ \\
Observations & 563 & 573 & 256 & 567 & 564 \\
R-squared & 0.060 & 0.095 & 0.109 & 0.085 & 0.088 \\
\hline
\end{tabular}

Robust standard errors in parentheses: ${ }^{* * *} \mathrm{p}<0.01,{ }^{* *} \mathrm{p}<0.05,{ }^{*} \mathrm{p}<0.1$. All regressions include regional and industry dummies. TSMP is Total Sales of the Main Product, TS-Total sales, ATS-Average Total Sales, TSSM-Total Sales of the Slowest Month, TSBM-Total Sales of the Busiest Month.

\footnotetext{
${ }^{16}$ We estimated this for the other two bank financing variables (Bank Dummy and Investment Finance Dummy) and the results were similar to those of tables 5 and 6. However, in the case of the Investment Finance Dummy, the instrument did not pass the test of weak instrument. First stage results can be found in the Appendix.
} 
As described in Section 3, we used an instrumental variable technique to deal with this problem. We estimated a 2SLS regression with collateral17 as an instrument. In Table 8, after instrumenting for past finance dummy, the result is comparable to the ones in Table 4. We observed a positive sign for our bank financing variable in the case of all the 4 different dependent variables. In Columns 2, 4 and 5, we have statistically significant coefficients that are bigger than those in Table 4. The magnitude effects are even larger in the estimation. Our results here confirm our earlier results to be robust; hence, formal financing promotes the growth of informal firms in Ghana. ${ }^{18}$

We examined the robustness of the estimation in Table 8. The key variable in the 2SLS estimation is the instrument-in this case, which is collateral (Cameron et al. 2010). If this instrument is not valid, then the results above are also not valid. Using the first stage F-stat, we tested for weak instrument. In all five columns, our estimations are valid as the test of weak instrument is satisfactorily met.

\footnotetext{
${ }^{17}$ Collateral is represented by a variable that measures collateral requirement for loan. It captures both personal and physical guarantees required to qualify for a loan.

18 Almost all the control variables had the right signs and are significant.
} 
Table 9: Firm growth and financing-Heckman Selection regression

\begin{tabular}{|c|c|c|c|c|c|c|c|c|c|c|}
\hline VARIABLES & $\begin{array}{c}\text { TSMP } \\
(1)\end{array}$ & $\begin{array}{l}\mathrm{SE} \\
(2) \\
\end{array}$ & $\begin{array}{l}\text { TS } \\
(3) \\
\end{array}$ & $\begin{array}{l}\text { SE } \\
(4) \\
\end{array}$ & $\begin{array}{c}\text { ATS } \\
(5)\end{array}$ & $\begin{array}{l}\text { SE } \\
(6) \\
\end{array}$ & $\begin{array}{c}\text { TSSM } \\
(7)\end{array}$ & $\begin{array}{l}\text { SE } \\
(8) \\
\end{array}$ & $\begin{array}{c}\text { TSBM } \\
(9) \\
\end{array}$ & $\begin{array}{c}\text { SE } \\
(10) \\
\end{array}$ \\
\hline Past Finance Dummy & $\begin{array}{c}0.364 * * \\
(0.147)\end{array}$ & & $\begin{array}{c}0.417 * * * \\
(0.128)\end{array}$ & & $\begin{array}{c}0.157 \\
(0.350)\end{array}$ & & $\begin{array}{c}0.477 * * * \\
(0.148)\end{array}$ & & $\begin{array}{c}0.343 * * * \\
(0.132)\end{array}$ & \\
\hline Age & $\begin{array}{c}0.132 \\
(0.087)\end{array}$ & $\begin{array}{c}0.039 \\
(0.120)\end{array}$ & $\begin{array}{c}0.184^{* *} \\
(0.086)\end{array}$ & $\begin{array}{l}-0.053 \\
(0.123)\end{array}$ & $\begin{array}{c}0.342 \\
(0.372)\end{array}$ & $\begin{array}{l}-0.057 \\
(0.090)\end{array}$ & $\begin{array}{c}0.145 \\
(0.110)\end{array}$ & $\begin{array}{c}0.063 \\
(0.122)\end{array}$ & $\begin{array}{c}0.140 \\
(0.096)\end{array}$ & $\begin{array}{c}0.008 \\
(0.119)\end{array}$ \\
\hline legal status & $\begin{array}{l}0.629 * \\
(0.330)\end{array}$ & $\begin{array}{l}-0.323 \\
(0.370)\end{array}$ & $\begin{array}{c}0.660^{* *} \\
(0.291)\end{array}$ & $\begin{array}{l}-0.007 \\
(0.426)\end{array}$ & $\begin{array}{l}-0.928 \\
(2.665)\end{array}$ & $\begin{array}{l}0.579 * \\
(0.311)\end{array}$ & $\begin{array}{c}0.883^{* *} \\
(0.410)\end{array}$ & $\begin{array}{c}0.517 \\
(0.544)\end{array}$ & $\begin{array}{c}0.716^{* *} \\
(0.362)\end{array}$ & $\begin{array}{c}0.527 \\
(0.542)\end{array}$ \\
\hline firm size & $\begin{array}{c}0.085 \\
(0.221)\end{array}$ & $\begin{array}{c}-0.710^{* * *} \\
(0.156)\end{array}$ & $\begin{array}{c}0.291 \\
(0.258)\end{array}$ & $\begin{array}{c}-0.720^{* * *} \\
(0.163)\end{array}$ & $\begin{array}{c}0.404 \\
(0.351)\end{array}$ & $\begin{array}{l}-0.029 \\
(0.111)\end{array}$ & $\begin{array}{l}-0.108 \\
(0.310)\end{array}$ & $\begin{array}{c}-0.811^{* * *} \\
(0.163)\end{array}$ & $\begin{array}{c}0.082 \\
(0.266)\end{array}$ & $\begin{array}{c}-0.716^{* * *} \\
(0.157)\end{array}$ \\
\hline Ownership & $\begin{array}{l}-0.032 \\
(0.172)\end{array}$ & $\begin{array}{c}0.010 \\
(0.223)\end{array}$ & $\begin{array}{c}0.080 \\
(0.165)\end{array}$ & $\begin{array}{c}0.065 \\
(0.223)\end{array}$ & $\begin{array}{c}0.642 \\
(1.411)\end{array}$ & $\begin{array}{c}-0.290 * \\
(0.172)\end{array}$ & $\begin{array}{c}0.079 \\
(0.230)\end{array}$ & $\begin{array}{l}-0.222 \\
(0.246)\end{array}$ & $\begin{array}{c}0.123 \\
(0.205)\end{array}$ & $\begin{array}{l}-0.238 \\
(0.245)\end{array}$ \\
\hline Competition & $\begin{array}{c}0.030 \\
(0.101)\end{array}$ & $\begin{array}{c}0.021 \\
(0.136)\end{array}$ & $\begin{array}{c}0.022 \\
(0.118)\end{array}$ & $\begin{array}{l}-0.185 \\
(0.140)\end{array}$ & $\begin{array}{l}-0.018 \\
(0.562)\end{array}$ & $\begin{array}{l}-0.102 \\
(0.103)\end{array}$ & $\begin{array}{l}-0.168 \\
(0.134)\end{array}$ & $\begin{array}{l}-0.111 \\
(0.139)\end{array}$ & $\begin{array}{l}-0.120 \\
(0.113)\end{array}$ & $\begin{array}{l}-0.067 \\
(0.137)\end{array}$ \\
\hline education level & $\begin{array}{c}0.138^{* *} \\
(0.064)\end{array}$ & $\begin{array}{l}-0.089 \\
(0.071)\end{array}$ & $\begin{array}{c}0.178^{* * *} \\
(0.063)\end{array}$ & $\begin{array}{l}-0.084 \\
(0.072)\end{array}$ & $\begin{array}{c}0.245 \\
(0.160)\end{array}$ & $\begin{array}{c}0.002 \\
(0.056)\end{array}$ & $\begin{array}{c}0.057 \\
(0.082)\end{array}$ & $\begin{array}{l}-0.094 \\
(0.071)\end{array}$ & $\begin{array}{c}0.142 * * \\
(0.072)\end{array}$ & $\begin{array}{l}-0.088 \\
(0.071)\end{array}$ \\
\hline electricity outage & $\begin{array}{l}-0.008 \\
(0.125)\end{array}$ & $\begin{array}{c}0.228 \\
(0.140)\end{array}$ & $\begin{array}{l}-0.089 \\
(0.111)\end{array}$ & $\begin{array}{c}0.145 \\
(0.146)\end{array}$ & $\begin{array}{c}0.366 \\
(0.762)\end{array}$ & $\begin{array}{l}-0.151 \\
(0.108)\end{array}$ & $\begin{array}{c}0.088 \\
(0.137)\end{array}$ & $\begin{array}{c}0.100 \\
(0.144)\end{array}$ & $\begin{array}{l}-0.034 \\
(0.117)\end{array}$ & $\begin{array}{c}0.072 \\
(0.142)\end{array}$ \\
\hline Collateral & & $\begin{array}{c}-0.550^{* * *} \\
(0.204)\end{array}$ & & $\begin{array}{l}-0.332 \\
(0.222)\end{array}$ & & $\begin{array}{c}0.120 \\
(0.174)\end{array}$ & & $\begin{array}{l}-0.182 \\
(0.231)\end{array}$ & & $\begin{array}{l}-0.226 \\
(0.223)\end{array}$ \\
\hline lambda & $\begin{array}{c}0.205 \\
(0.961)\end{array}$ & & $\begin{array}{l}-0.428 \\
(1.253)\end{array}$ & & $\begin{array}{l}-2.851 \\
(6.819)\end{array}$ & & $\begin{array}{c}1.513 \\
(1.281)\end{array}$ & & $\begin{array}{c}1.207 \\
(1.195)\end{array}$ & \\
\hline Constant & $\begin{array}{c}5.458 * * * \\
(0.308)\end{array}$ & $\begin{array}{c}1.645^{* * *} \\
(0.393)\end{array}$ & $\begin{array}{c}5.686^{* * *} \\
(0.291)\end{array}$ & $\begin{array}{c}1.821^{* * *} \\
(0.402)\end{array}$ & $\begin{array}{c}6.870 \\
(4.344)\end{array}$ & $\begin{array}{c}0.249 \\
(0.304)\end{array}$ & $\begin{array}{c}5.042^{* * *} \\
(0.384)\end{array}$ & $\begin{array}{c}1.696^{* * *} \\
(0.410)\end{array}$ & $\begin{array}{c}5.909 * * * \\
(0.333)\end{array}$ & $\begin{array}{c}1.696^{* * *} \\
(0.406)\end{array}$ \\
\hline
\end{tabular}

Observations

$648 \quad 648$

648

648

648

648

648

648

Robust standard errors in parentheses: ${ }^{* * *} \mathrm{p}<0.01,{ }^{* *} \mathrm{p}<0.05,{ }^{*} \mathrm{p}<0.1$. All regressions include regional and industry dummies. TSMP is Total Sales of the Main Product, TS-Total sales, ATS-Average Total Sales, TSSM-Total Sales of the Slowest Month, TSBM-Total Sales of the Busiest Month, SE-Selection Equation. Lambda coefficient captures the effect of selection. 


\subsubsection{Heckman selection model}

A selection effect is a likely problem in this study as described in section $3^{19}$. Therefore, we also investigated the impact of financing options on firm performance, controlling for selection bias. We estimated the Heckman two-stage selection model using Equations 2 and 3 in Section 3. From Table 9, the results show that formal financing is positively associated with firm growth. Coefficient estimates of the past finance dummy are positive and significant. These results improve on the results in Table 3 with larger coefficients for the bank financing variable in columns 2 and 4. ${ }^{20}$

\section{DISCUSSION}

In this section, we explore how our results fit into the literature on financing and firm growth. Our investigation reveals that formal finance significantly supports firm growth in the case of Ghana. While the data and descriptive statistics show a predominant use of informal finance by the firms captured in the survey, our regression results reveal that formal financing promoted firm growth. This result is similar to several studies in this field. In his study on Ghana, Aryeetey (1998) shows that external finance from banks is essential and indispensable for small and medium scale industries, despite the use of internal sources of funding. He argues that these informal sources of finance were unstable since such informal sources failed from time to time. Delivery of credit by these sources was equally not appropriately done. This study was not just descriptive and therefore contributes to the literature beyond Ghana by providing a more detailed analysis of financing and firm growth relationship using different estimation techniques and robustness checks. Ayyagari et al. (2010) used a similar survey data by the World Bank to show evidence of a positive association

\footnotetext{
${ }^{19}$ See Li et al. (2007) for a summary and examples of other studies that apply the selection model to control for the impact of selection bias on the coefficient estimates.

${ }^{20}$ We estimate the selection model using the bank dummy and investment finance dummy variable and results were still consistent.
} 
between bank finance and firm growth in China. Using a series of techniques, including the Heckman selection, they show how bank financing promotes reinvestment rate and productivity growth. Similar to Ayyagari et al. (2010), Cull et al. (2005) found that greater access to bank financing is associated with higher reinvestment in China. They also explore different external forms of financing in the presence of inefficiencies and provide evidence to support formal financing in China. Despite these important studies, our study still contributes to the literature with our unique approach. Our study covered only informal firms in Ghana unlike these other studies $^{21}$.

Our results do not completely discard the important role of internal financing in firm growth. In our results on firm size, we obtained a positive relationship between firm growth and firm size for both large and small firms. However, the coefficient estimate for small firms was much smaller. This suggests the relevance of other sources of financing especially to the development of small firms. This result is similar to the study by Girma et al. (2009). They provide evidence to support the fact that formal financing has a greater influence on the growth of large firms while internal finance was relevant to the growth of small firms in China. In addition, we contribute to the theoretical literature by using a model which takes into consideration the selection process of firm financing.

\section{Conclusion}

The focus of this research was to identify whether formal or informal sources of financing promote firm growth and hence provide a research led policy initiative. We hypothesized that, given that these two types of financing provide unique benefits, identifying which channel operates in Ghana for informal firms would lead to policy recommendations to promote the use of the other

\footnotetext{
${ }^{21}$ See Cheng et al. (2006), Fan et al. (2005) for similar results on bank financing and firm growth.
} 
channels. This outcome will potentially help to identify whether there is a substitute or complementary relationship between formal and informal forms of financing in Ghana.

Using firm level data covering 720 informal firms in Ghana, we investigated the relationship between firm financing and their performance. We explored formal financing versus informal financing and how they affect firm's growth performance. Using different estimation techniques and controlling for endogeneity, we observed that formal finance is positively associated with firm growth. In the presence of different measures of a firm's performance and using bank finance to proxy for formal finance, we identified that bank finance promotes firm growth, especially for large firms. Contrary to popular view that informal finance is suitable to SME's, this result presents a key policy.

These findings can help governments and stakeholders create a suitable environment for the general growth of informal firms. Formal finance is generally considered to be a preferred option for big firms. But in this study, we have shown that policy makers in developing countries like Ghana can boost growth of informal firms by creating easy access to formal finance for informal firms. Firstly, governments in partnership with the Bank of Ghana can create incentives that encourage formal financing institutions to lend financial support to informal firms. Formal finance institutions with several years of experience in financing and working with more firms than informal finance institutions can provide more than just finance to informal firms which need more education in their financial management and choices (Allen et al. 2000). Such support will provide greater output and growth sales. Secondly, as a policy initiative, Government can provide education to these informal firms on how to manage their business in such a way to make them attractive to formal finance institutions for investment. These policy recommendations must be 
implemented together to avoid coordination failure. A state where the formal financial institutions make the provision (of incentives by Government) to equally accommodate informal firms and informal firms also make the investment to position their business to work with formal financial institutions would prevent the possibility of one group shirking. This is why government's intervention is important.

Another policy recommendation is for Government to properly streamline the informal financial sector as they are still relevant to the very small firms as confirmed by our results. In providing support for such sectors to thrive, there should be clarity in the regulations governing their activities and, more importantly, key milestones to monitor their development to improve their support for the informal sector. Firms and financial institutions can take up new opportunities when some of these obstacles are removed by policy makers. 


\section{Reference}

Abor, J., and Quartey, P. 2010. "Issues in SME development in Ghana and South Africa." International research journal of finance and economics 39: 218-228.

Allen, F., Mejuin, M. and Xie, J. 2019. "Understanding Informal Financing." Journal of Formal Intermediation 39: 19-33.

Allen, F., J. Qian, and M. Qian. 2005. "Law, finance, and economic growth in China." Journal of Financial Economics 77: 57-116.

Antras, P., E. and Helpman. 2004. "Global Sourcing." Journal of Political Economy, 112(3), 552-580.

Arias, O., P. Fajnzylber, W. Maloney, A. Mason, G. Perry, and J. Saavedra-Chanduvi. (2007). Informality: exit and exclusion. Washington: The World Bank.

Arthur, P. 2003. "The implications of state policy for micro-enterprise development." In: Tettey, Wisdom, Puplampu, Korbla, Berman, Bruce (Eds.) (2003). Critical Perspectives on Politics and SocioEconomic Development in Ghana. Leiden, 153-175.

Aryeetey, E. 1994. "Supply and Demand for Finance of Small Enterprises in Ghana". World Bank Discussion Paper 251. The World Bank, Washington, D.C.

Aryeetey, E. 1998. "Informal Finance for Private Sector Development in Africa." African Development Report, Institute of Statistical, Social and Economic Research, Ghana.

Asamoah, E. S., and F. Doe. 2014. "The Effect of Electric Power Fluctuations on the profitability and Competitivenss of SMEs: A study of SMEs within the Accra Business District of Ghana." Journal of Competitiveness 6: 32-48.

Ayyagari, M., A. Demirguc-Kunt., and V. Maksimovic. 2008. "How Important Are Financing Constraints? The Role of Finance in the Business Environment." World Bank Economic Review 22: 483-516.

Ayyagari, M., A. Demirgüç-Kunt, and V. Maksimovic. 2010. "Formal versus informal finance: evidence from China." Review of Financial Studies 23: 3048-3097.

Ayyagari, M., A. Demirguc-Kunt., and V. Maksimovic. 2011. "Small vs. Young Firms Across the World: Contribution to Employment, Job Creation, and Growth." World Bank Policy Research Working Paper 5631.

Baah-Nuakoh, A., F. E. Turkson, K. Baah-Nuakoh, and W. Baah-Boateng. 2002. "Multi country study on Transformation of Small firms in Africa: The Case of Ghana Research Report." African Center for Economic Growth, Kenya.

Berg, G. and M. Fuchs. 2013. "Bank Financing of SMEs in Five sub-Saharan African Countries: The Role of Competition, Innovation, and the Government." Policy Research Working Paper/WPS6563, the World Bank. 
Beck, T., A. Demirgüç-Kunt, L. Laeven, and V. Maksimovic. 2006a. "The Determinants of Financing Obstacles." Journal of International Money and Finance 25: 932-52.

Beck, T., A. Demirgüç-Kunt, and V. Maksimovic. 2006b. "The Influence of Financial and Legal Institutions and Firm Size.” Journal of Banking and Finance 30: 2995-3015.

Beck, T., A. Demirgüç-Kunt, and V. Maksimovic. 2005. "Financial and Legal Constraints to Firm Growth: Does Firm Size Matter? Journal of Finance 60: 137-177.

Beck, T., and R. Cull. 2014. "Banking in Africa." In: Berger, Allen, Phil Molyneux and John Wilson (Eds.): Oxford Handbook of Banking, 2nd edition.

Beck, T., S. M. Maimbo, I., Faye, and T. Triki. 2011. "Financing Africa through the Crisis and Beyond." World Bank, Washington.

Beck, T., L. Lu and R. Yang. 2015. "Finance and Growth of Microenterprises: Evidence from Rural China” World Development 67: 38-56.

Berger, A. N., and G. F. Udell. 1998. "The economics of small business finance: The roles of private equity and debt markets in the financial growth cycle." Journal of banking \& finance, 22(6-8), 613-673.

Bigsten, A., P. Collier, S. Dercon, M. Fafchamps, B. Guthier, and W. Gunning. 2000. "Credit Constraints in Manufacturing Enterprises in Africa." Working Paper WPS/2000. Centre for the study of African Economies, Oxford University, Oxford

Boot, A. W., and A. V. Thakor. 1994. "Moral hazard and secured lending in an infinitely repeated credit market game”. International Economic Review, 899-920.

Cameron, A. C., and P. K. Trivedi. 2010. "Microeconometrics using Stata.” Stata Press.

Carpenter, R., B. Petersen. 2002. "Is the growth of small firms constrained by internal finance?" Review of Economics and Statistics 84, 298-309.

Charmes, J. 2000. "The Contribution of Informal Sector to GDP in Developing Countries: Assessment, Estimates, Methods, Orientations for the Future." OECD-EUROSTAT-State Statistical Committee of the Russian Federation, Non-Observed Economy Workshop, Sochi (Russia), October 16-20.

Christensen, C. M., and A. D. Scott. 2004. "New Avenues to Growth." Strategy \& Innovation 2:6 (November 15, 2004)

Christopoulos, D. K., E. G. Tsionas. 2004. "Financial Development and Economic Growth: Evidence from Panel Unit Root and Cointegration Tests." Journal of Development Economics, 73: 5574.

Collier, P. 2009. "Rethinking Finance for Africa's Small Firms in "SME Financing in SSA," Private Sector and Development, Proparco's Magazine, 1:3-4. 
Cull, R., and L. C. Xu. 2005. "Institutions, ownership, and finance. The determinants of profit reinvestment among Chinese firms." Journal of Financial Economics, 77: 117-46.

Cull, R., L. C. Xu, and T. Zhu. 2009. "Formal finance and trade credit during China's transition." Journal of Financial Intermediation 18: 173-192.

De Soto, H. 1989. “The Other Path: The Invisible Revolution in the Third World.” New York: Harper \& Row.

Deakins, D., D. North, R. Baldock, and G. Whittam. 2008. 'SMEs' Access to Finance: Is There Still a Debt Finance Gap?” Institute for Small Business\& Entrepreneurship. 3: 1-19.

Degryse H., L. Lu, and S. Ongena. 2016. "Informal or Formal Financing? Evidence in the Cofounding of Chinese firms." Journal of Financial Intermediation 27: 13-50.

Fan, G., and X. Wang. 2005. "NERI Index of Marketization of China's provinces 2004 Report." National Economic Research Institutes, China Reform Foundation, Economics Science Press.

Fafchamps, M. 1994. "Industrial structure and micro-enterprises in Africa." The Journal of Developing Areas 29:1 -30.

Ghana Statistical Service. 2008. "Ghana Living Standards Survey": Report of the Fifth Round (V) Accra.

Ghana Statistical Service. 2015. "Integrated Business Establishment Survey (IBES)": Report of the Fifth Round (V) Accra.

Girma, S., Y. Gong, H. Görg, and Z. Yu. 2009. "Can production subsidies explain China's export performance? Evidence from firm-level data." The Scandinavian Journal of Economics, 111: (4) 863891

Girma, S., and J. Du. 2012. "Firm Size, Source of Finance, and Growth - Evidence from China." International Journal of the Economics of Business, 19:3, 397-419

Guariglia, A., X. Liu, and L. Song. 2011. "Internal finance and growth: Microeconometric evidence on Chinese firms." Journal of Development Economics 96, 1, 79-94.

Guariglia, A., S. Ding, and J. Knight. 2013. "Investment and financing constraints in China: Does working capital management make a difference?” Journal of Banking \& Finance, 37(5), 1490-1507.

Guariglia, A. 2008. "Internal financial constraints, external financial constraints, and investment choice: evidence from a panel of UK firms." Journal of Banking and Finance 32, 1795-1809.

Hormeku, T. 1998. "The Transformation and Development of the Informal Sector and the Role of Trade Unions," Paper prepared for an OATUU/ILO/ETUF Seminar on "Trade unions and the informal sector", Cairo, Egypt, 4-6 May

Helpman, E., M. Melitz, S. R. Yeaple. 2004. "Export versus FDI with Heterogeneous Firms.” American Economic Review, 94(1): 300-316. 
Helpman E, M. Melitz, and Y. Rubinstein. 2008. "Estimating trade flows: Trading partners and trading volumes". The quarterly journal of economics 123: 441-487

Jensen, M. C., W. H. Meckling. 1976. "Theory of the firm: Managerial behavior, agency costs and ownership structure.” Journal of financial economics, 3(4), pp.305-360.

Khan, S. 2015. "Impact of Sources of Finance on the growth of SME's: Evidence from Pakistan" Decision 42(1), pp.3-10.

Levine, R. 2005. "Finance and Growth: Theory and Evidence. In: Aghion, P and Durlauf, S." (eds.), Handbook of Economic Growth. Elsevier Science. The Netherlands.

Li, K., and N. Prabhala. 2007. "Self-Selection Models in Corporate Finance." In B. Espen Eckbo (ed.), Handbook of Empirical Corporate Finance, chapter 2, pp. 37-83. Amsterdam, the Netherlands: Elsevier.

Li, J., and S. Hsu. 2009. "Informal Finance in China." American and Chinese Perspectives, Oxford University Press, New York.

Magoutas, A. I., T. A. Papadogona, and G. Sfakianakis. 2012. "Market Structure, Education, and Growth.” International Journal of business and Social Science, 3: 12.

Megginson, W. L., and J. Netter. 2001. "From State to Market: A Survey of Empirical Studies on Privatization." Journal of Economic Literature, 39(2) 321-389.

Mensah, S. 2004. "A Review of SME Financing Schemes in Ghana”. UNIDO Regional Workshop of Financing SMEs, Accra.

Modigliani, F., M. H. Miller.1958. "The cost of capital, corporation finance and the theory of investment." The American, 1:3.

Myers, S. C. 1984. “The capital structure puzzle.” The Journal of finance, 39(3), 574-592.

Nugent, J., B. 1996. "What explains the trend reversal in the size distribution of Korean manufacturing establishments?" Journal of Development Economics 48, 225-251.

Nyamekye, M., N. Koboré, E. R. Bonégo, E. Kiéma B. Ndour, S. Jallo, and M. S. Tarawally. 2009. "Organizing Informal Sector Workers in West Africa: focus on Women Workers, Trade Union Strategies." Case Studies from Ghana, Sierra Leone, Senegal and Burkina Faso" Accra, Ghana Trades Union Congress.

Okpara, J. O. 2011. "Factors constraining the growth and survival of SMEs in Nigeria: implications for poverty alleviation.” Management Research. Review 34 (2),156-171.

Quartey, P. 2002. "Financing Small and Medium-sized Enterprises in Ghana." Journal of African Business, 4: 37-56.

Quartey, P., Turkson, F.E, Abor, J.Y \& Iddrissu, A.M. 2017. Financing the Growth of SMEs in Africa: What are the Constraints to SME Financing within ECOWAS? Review of Development Finance 7 (2017) $18-28$ 
Shleifer, A. 1998. State versus Private Ownership, Journal of Economic Perspective, 12, 133-150.

Sleuwaegen, L., and Goedhuys, M. 2002. Growth of Firms in Developing countries, Evidence from Cote d'Tvoirell Journal of Development Economics, 68 (1) 117-135.

Turkson F. E. 2010. "Firm Growth Dynamics in Africa: Evidence from the Manufacturing Sector in Ghana." Journal of Business Research, 4, 141-169.

Tybout, J. R. 2000. "Manufacturing firms in developing countries: how well do they do and why." Journal of Economic Literature 38, 11 - 44.

World Bank. 1994. "Industrial Structures and the Development of Small and Medium Enterprise Linkages:” Examples from East Asia, Meyanathan S. (Ed.), EDI Series, World Bank.

Yankson P. 1985. "Employment and Income Generation in the Petty Commodity Sector of the Urban Economy: the Case Study of the Central region of Ghana." Africa Development 8(4), pp.7596.

Yeaple, S. 2005. “A simple model of firm heterogeneity, international trade, and wages.” Journal of international Economics 65 (1), 1-20.

Zingales, L., and S. N. Kaplan. 2000. "Investment-cash flow sensitivities are not valid measures of financing constraints." The Quarterly Journal of Economics, 115(2), 707-712.

\section{Appendix}

First stage results for table 8 . 


\begin{tabular}{|c|c|c|c|c|c|}
\hline VARIABLES & $\begin{array}{c}\text { TSMP } \\
\text { (1) }\end{array}$ & $\begin{array}{l}\text { TS } \\
\text { (2) }\end{array}$ & $\begin{array}{c}\text { ATS } \\
\text { (3) }\end{array}$ & $\begin{array}{c}\text { TSSM } \\
(4)\end{array}$ & $\begin{array}{c}\text { TSBM } \\
(5)\end{array}$ \\
\hline Collateral & $\begin{array}{c}0.203 * * * \\
(0.083)\end{array}$ & $\begin{array}{c}0.819 * * * \\
(0.039)\end{array}$ & $\begin{array}{c}0.868 * * * \\
(0.052)\end{array}$ & $\begin{array}{c}0.820 * * * \\
(0.039)\end{array}$ & $\begin{array}{c}0.818^{* * *} \\
(0.039)\end{array}$ \\
\hline Age & $\begin{array}{c}0.002 \\
(0.024)\end{array}$ & $\begin{array}{c}0.004 \\
(0.024)\end{array}$ & $\begin{array}{c}0.008 \\
(0.032)\end{array}$ & $\begin{array}{c}0.009 \\
(0.023)\end{array}$ & $\begin{array}{c}0.009 \\
(0.024)\end{array}$ \\
\hline legal status & $\begin{array}{l}-0.029 \\
(0.072)\end{array}$ & $\begin{array}{l}-0.037 \\
(0.068)\end{array}$ & $\begin{array}{c}0.007 \\
(0.107)\end{array}$ & $\begin{array}{l}-0.039 \\
(0.064)\end{array}$ & $\begin{array}{l}-0.040 \\
(0.063)\end{array}$ \\
\hline firm size & $\begin{array}{l}0.055^{*} \\
(0.03)\end{array}$ & $\begin{array}{c}0.057^{* *} \\
(0.029)\end{array}$ & $\begin{array}{c}0.050 \\
(0.046)\end{array}$ & $\begin{array}{c}0.066^{* *} \\
(0.030)\end{array}$ & $\begin{array}{c}0.064^{* *} \\
(0.030)\end{array}$ \\
\hline Ownership & $\begin{array}{c}0.018 \\
(0.040)\end{array}$ & $\begin{array}{c}0.020 \\
(0.040)\end{array}$ & $\begin{array}{c}0.037 \\
(0.044)\end{array}$ & $\begin{array}{c}0.025 \\
(0.039)\end{array}$ & $\begin{array}{c}0.025 \\
(0.039)\end{array}$ \\
\hline level of Competition2 & $\begin{array}{c}-0.068^{* *} \\
(0.027)\end{array}$ & $\begin{array}{l}0.70^{* *} \\
(0.027)\end{array}$ & $\begin{array}{l}-0.046 \\
(0.041)\end{array}$ & $\begin{array}{c}0.073^{* * *} \\
(0.027)\end{array}$ & $\begin{array}{c}0.074 * * * \\
(0.027)\end{array}$ \\
\hline education level & $\begin{array}{l}-0.021 \\
(0.014)\end{array}$ & $\begin{array}{l}0.022^{*} \\
(0.014)\end{array}$ & $\begin{array}{c}0.014 \\
(0.018)\end{array}$ & $\begin{array}{l}-0.224 \\
(0.013)\end{array}$ & $\begin{array}{l}-0.022 \\
(0.014)\end{array}$ \\
\hline electricity outage & $\begin{array}{l}0.012 \\
(0.03)\end{array}$ & $\begin{array}{c}0.006 \\
(0.029)\end{array}$ & $\begin{array}{c}0.005 \\
(0.048)\end{array}$ & $\begin{array}{c}0.015 \\
(0.029)\end{array}$ & $\begin{array}{c}0.016 \\
(0.029)\end{array}$ \\
\hline Constant & $\begin{array}{c}0.203^{* *} \\
(0.083)\end{array}$ & $\begin{array}{c}0.207^{* *} \\
(0.083)\end{array}$ & $\begin{array}{c}0.082 \\
(0.091)\end{array}$ & $\begin{array}{c}0.185^{* *} \\
(0.081)\end{array}$ & $\begin{array}{c}0.0184^{* *} \\
(0.081)\end{array}$ \\
\hline Observations & 563 & 573 & 256 & 567 & 564 \\
\hline R-squared & 0.349 & 0.349 & 0.109 & 0.377 & 0.372 \\
\hline
\end{tabular}

Robust standard errors in parentheses: *** $\mathrm{p}<0.01,{ }^{* *} \mathrm{p}<0.05,{ }^{*} \mathrm{p}<0.1$. All regressions include regional and industry dummies. TSMP is Total Sales of the Main Product, TS-Total sales, ATS-Average Total Sales, TSSM-Total Sales of the Slowest Month, TSBM-Total Sales of the Busiest Month. 